\title{
SAND DRIFT AND GROWTH OF SAND DUNES ON THE JÆREN COAST, SOUTHWESTERN NORWAY
}

\author{
ALF TØRUM ${ }^{1} \&$ OVE TOBIAS GUDMESTAD ${ }^{2}$ \\ ${ }^{I}$ Norwegian University of Science and Technology, Department of Civil \\ and Transport Engineering, NTNU, Trondheim, Norway. \\ ${ }^{2}$ University of Stavanger, Stavanger, Norway.
}

\begin{abstract}
The Jæren coastline on the southwestern corner of Norway has some stretches of sandy beaches, although most of the Norwegian coastline is rocky and barren. This coastline faces the large waves of the North Sea and sees a storm surge level of $1.2 \mathrm{~m}$ above mean sea level. The beaches were formed primarily by moving ice during the glacial periods, and, following these periods, the water level in the area has been varying and was, 4000 years ago, approximately $5 \mathrm{~m}$ higher than it is today. Since then, the water level has steadily decreased until today's level. Archeologists have revealed approximately 2500-year-old farm fields, which more recently have been covered by thick Aeolian sand. This sand drift has been a problem for the farmers, as the wind has blown the sand such that it has been covering the cultivated fields. In the 1880s it was decided to plant marram grass, which has been successful in stopping the sand from blowing onto the farm fields. Today the beaches of the coastline are not eroding significantly. The paper discusses the evidence of sand dune growth on the Jæren coast and the reasons why there has been no significant long-term beach erosion in the area.
\end{abstract}

Keywords: Beach erosion, marram grass, Sand drift, Sand dune growth.

\section{INTRODUCTION}

The Norwegian coastline is mainly rocky. However, the Jæren coastline, south of the city of Stavanger on the southwestern tip of Norway, Fig. 1, has some stretches of beaches.

The South Norwegian Deep Channel, Fig. 1, that runs along the south coast of Norway is some $300 \mathrm{~m}$ deep and has been "carved" out by glaciers. The Lista-stage end moraine running along the coast is an end moraine left by glaciers. Figure 2 shows a more detailed map of the area at Revtangen, while Fig. 3 shows the beaches at Orre, south of Revtangen. The beaches and dunes consist of fine sand, gravel and even in some cases cobbles.

There are no big rivers entering the sea at Jæren. The sand, gravel and boulders on the sea bottom, on the beaches and on the land have been brought there by glaciers. Figure 4 shows how it is envisaged that the glaciers moved in this area during the last glaciations, for example, in the time period $29,000-15,000$ years ago.

Hardly any investigation has been carried out into the amount of sand and gravel and the number of boulders that are located on the beaches and in the sea around Jæren. However, during a drilling campaign, carried out in 1993 close to sea level at Grødaland, somewhat south of Revtangen, Fig. 1 [1], the drill-bit reached a depth of $123 \mathrm{~m}$ before it hit solid rock. The drill core contained clay, sand, gravel and some coarser material. Larsen et al. [2] refer to layers of moraine material several tens of meters thick along a transection from Auestad to Elgane, Fig. 4. It is thus obvious that large quantities of moraine material are available along the coast of and on land at Jæren.

The farmers at Reve have previously taken sand and gravel from the beach for use on their farms (for roads, ditches and concrete), but as the area has now been made into a landscape preservation area, the farmers are not allowed to use sand from the beach, except in very small quantities $\left(5 \mathrm{~m}^{3}\right.$ per year per farm). 


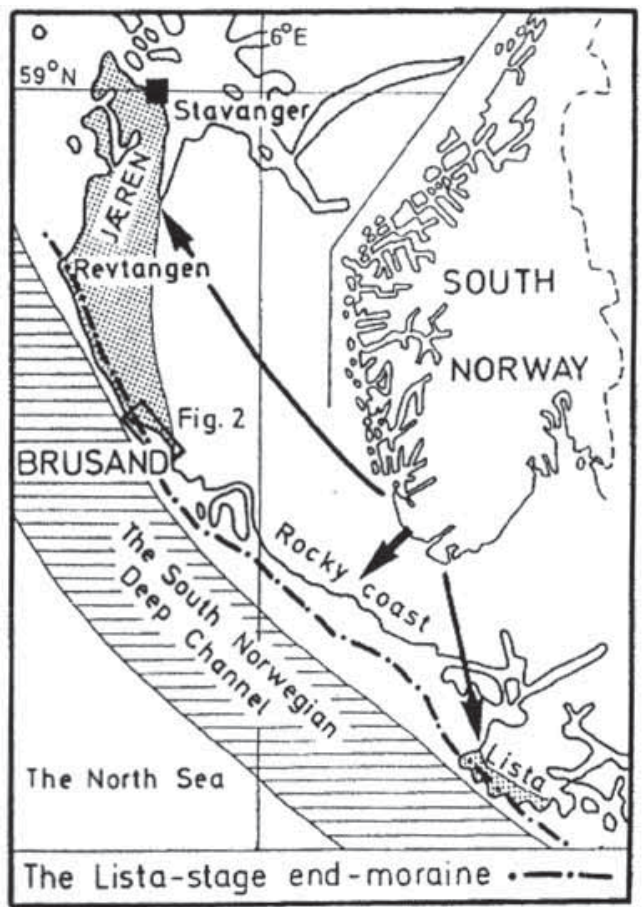

Figure 1: The location of Jæren at the southwestern tip of Norway [12].

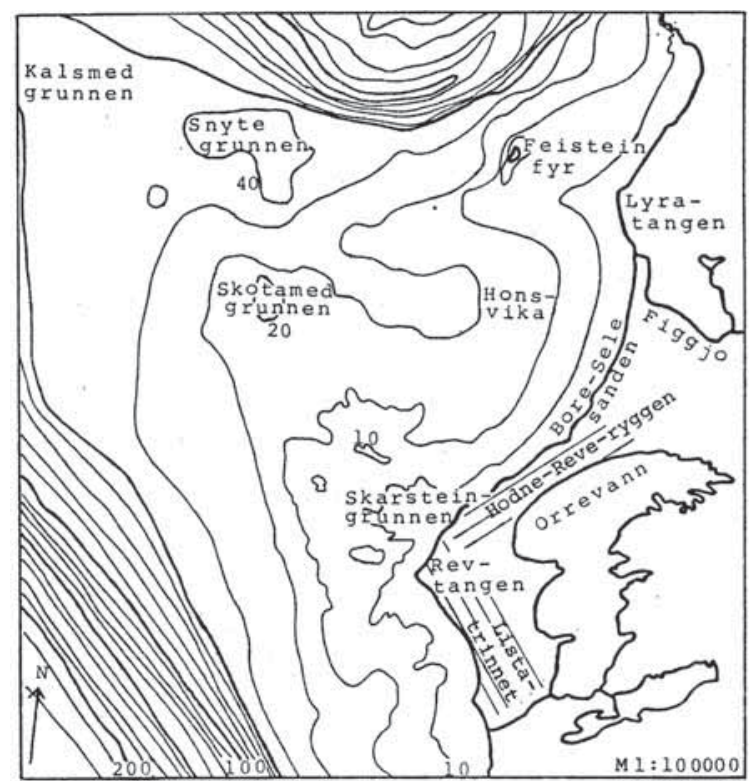

Figure 2: The area at Revtangen - Bore-Sele sanden. The Hodne-Reve ryggen (ridge approximately $7-12 \mathrm{~m}$ high) is a drumlin. "Listatrinnet" is the Lista-stage end moraine, which at Revtangen continues northwards into the sea. Note that the bottom slope is mild close to the coast but very steep into the South Norwegian Deep Channel. 


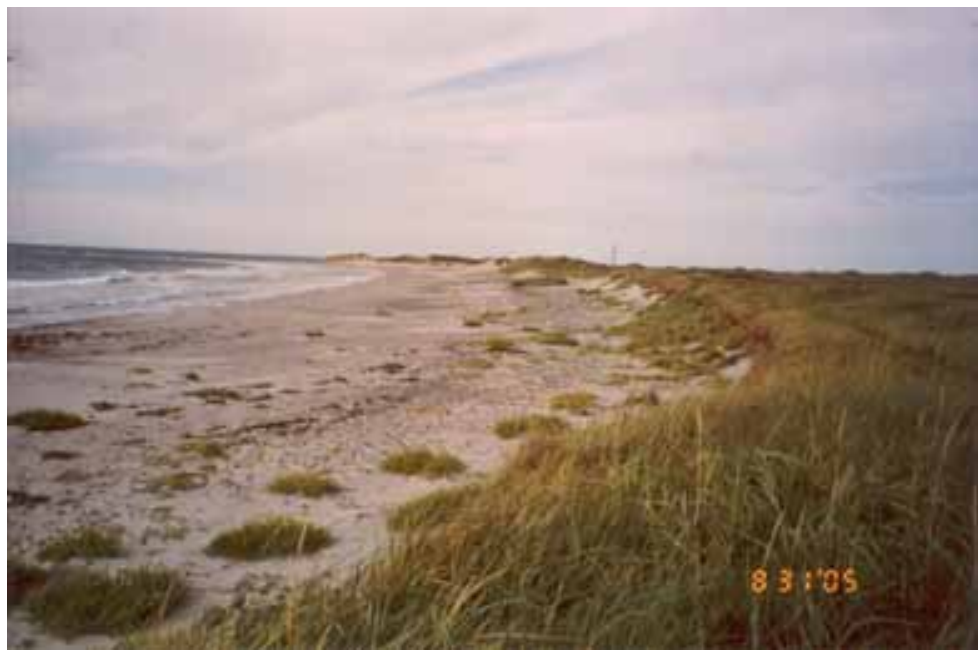

Figure 3: The beach and dunes at Orre, somewhat south of Revtangen in 2005.

\section{SAND DRIFT INVESTIGATIONS ON JÆREN}

The beaches along the Jæren coast are relatively stable; however, there are setbacks during heavy storms, Fig. 5. This setback is apparently temporary as the dunes grow again, as will be discussed later.

We will, however, first give an account of the Aeolian sand drift in the Jæren area, a drift that has been a nuisance to the farmers in the area, but which is now brought under control, mainly by planting marram grass (Ammophila areanana). Figure 6 shows a soil section from excavations at Stavanger airport, Sola [3]. The layer marked " 6 " is a peat layer. The thickness of the peat layer varies, reaching up to $80 \mathrm{~cm}$. The bottom of the peat layer is $C^{14}$ dated to $4540 \pm 90$ years before present (BP), while the upper part of layer " 6 " is dated to $2540 \pm 80$ years BP. Layer "7" is Aeolian sand (wind driven sand). While removing some of the peat layer, " 6 ", a series of tilled grooves were observed. They penetrated the peat layer and were interpreted as plough marks, reflecting cultivation dating to the time interval 2550-2200 years BP [3]. Pollen analysis from seven places in layer " 6 " also indicates that the land has been cultivated.

There has been discussion as to why the peat was later covered by the Aeolian sand layer. PrøschDanielsen indicates that the soil was exploited through farming, the rather thin soil layer to some extent disappeared, and the sand layers were "attacked" by the wind. Selsing and Mejdahl [4] also state that the anthropogenic impact on nature was the releasing factor for the Aeolian activity recorded in sand sheets. However, this may not necessarily be true. Nature itself has also contributed to this sand covering; this will be discussed later in this paper.

\section{WAVES, CURRENTS AND WATER LEVELS ON THE JÆREN COAST}

The Jæren coast faces the North Sea where wave conditions can be quite severe. The wave conditions were thoroughly investigated for a recently built breakwater at Sirevåg on the southern part of Jæren, close to Brusand, Fig. 1; see Table 1. The estimates were made from wave hindcast carried out by the Norwegian Meteorological Institute and by refraction analysis. During heavy storms in 2002 and 2005, the waves were close to the 100-year return period level. The Norwegian Coastal Current runs along the coast of Jæren today. 


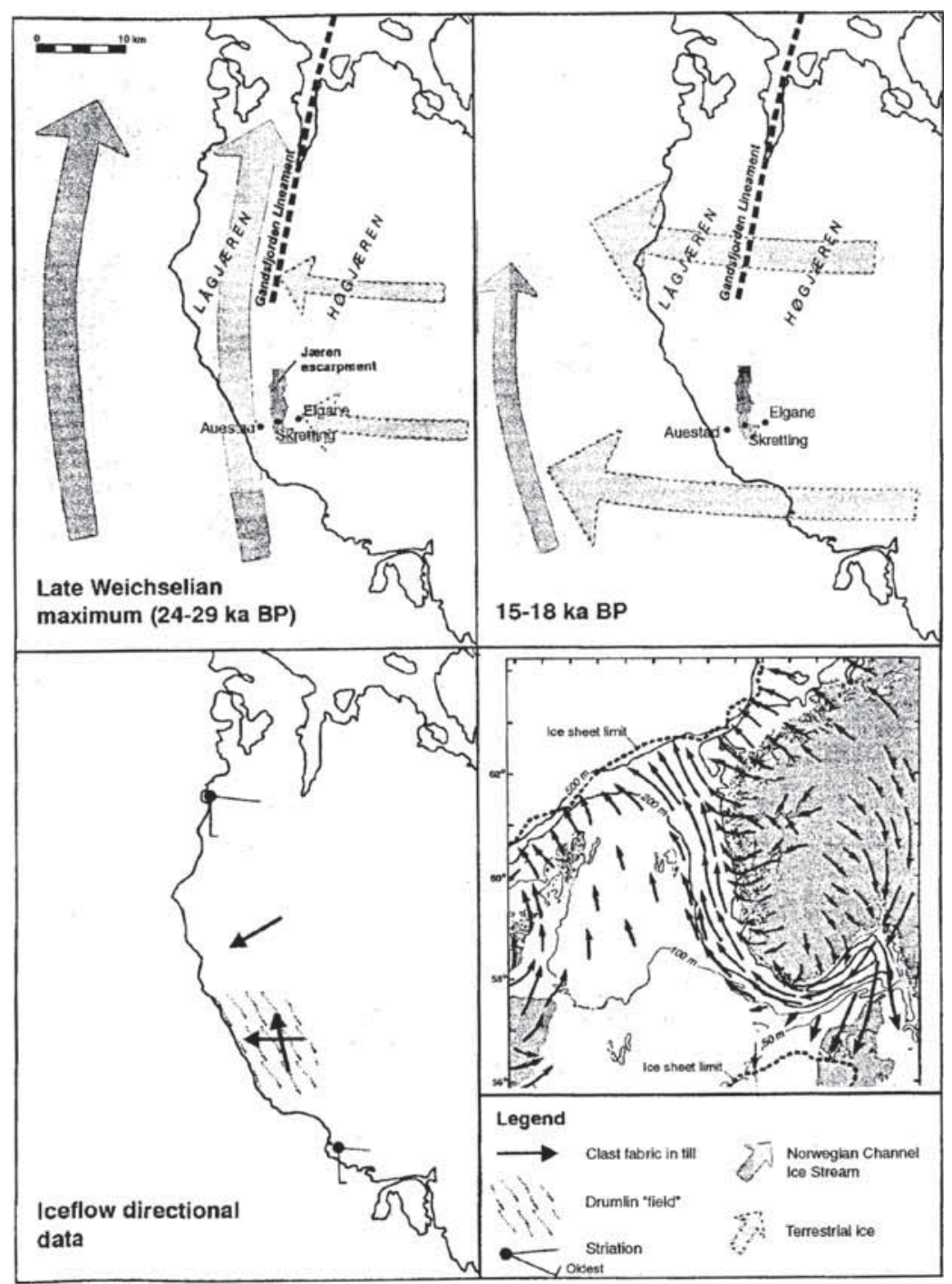

Figure 4: Interaction between the Norwegian Channel Ice Stream across Jæren at the Last Glacial Maximum followed by a glacier advance across the coastline by terrestrial-based ice about 18,000-15,000 years ago as the ice stream calved back into the Norwegian Channel. Some ice flow directional data from areas below the Jæren escarpment are also shown. The small map shows a more regional picture during maximum glaciations, modified from Sejrup et al. [26]. From Larsen et al. [2].

The tidal variation is small along the Jæren coast. Storm surges have larger impacts on the water level than the astronomical tide, Table. 1.

Løvås [5] investigated the simultaneous occurrence of water levels in Stavanger (where The Norwegian Mapping Authority has a permanent tide gauge station) and the significant wave heights in two grid points in deep water along the Jæren coast for the time period 1979-1997. The grid points 


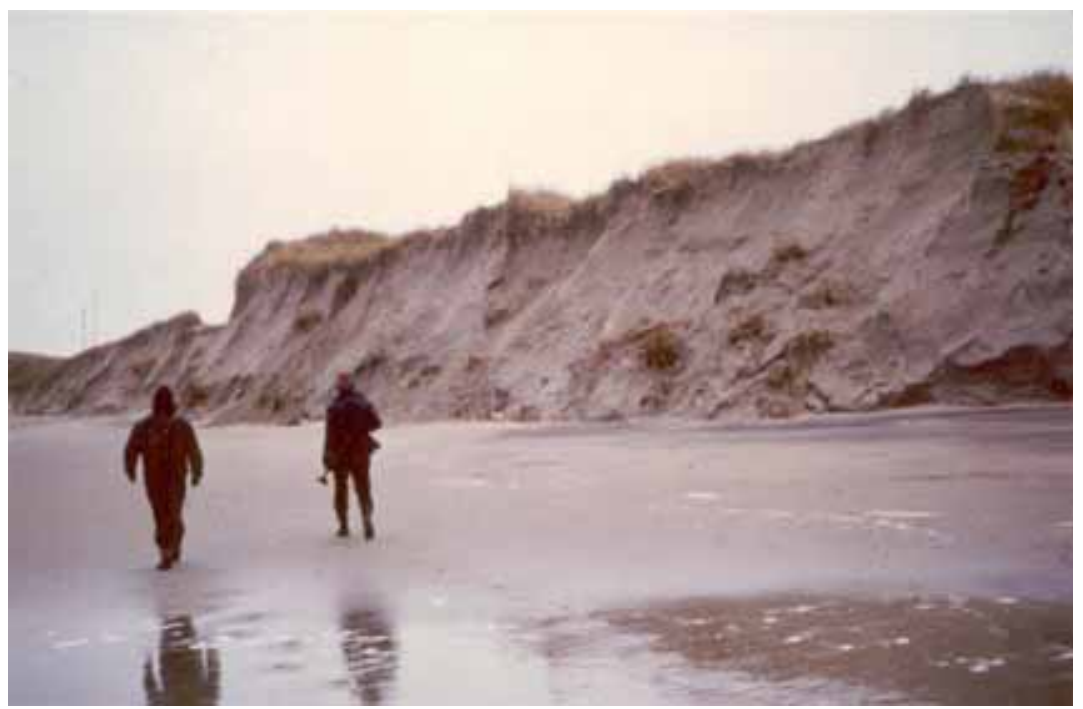

Figure 5: The sand dunes at Bore-Sele, Fig. 2, seen 2 days after a heavy storm in November 1981. In this case there has been considerable erosion of the beach and the dunes. The dune height is estimated to be $6-8 \mathrm{~m} \mathrm{[27].}$

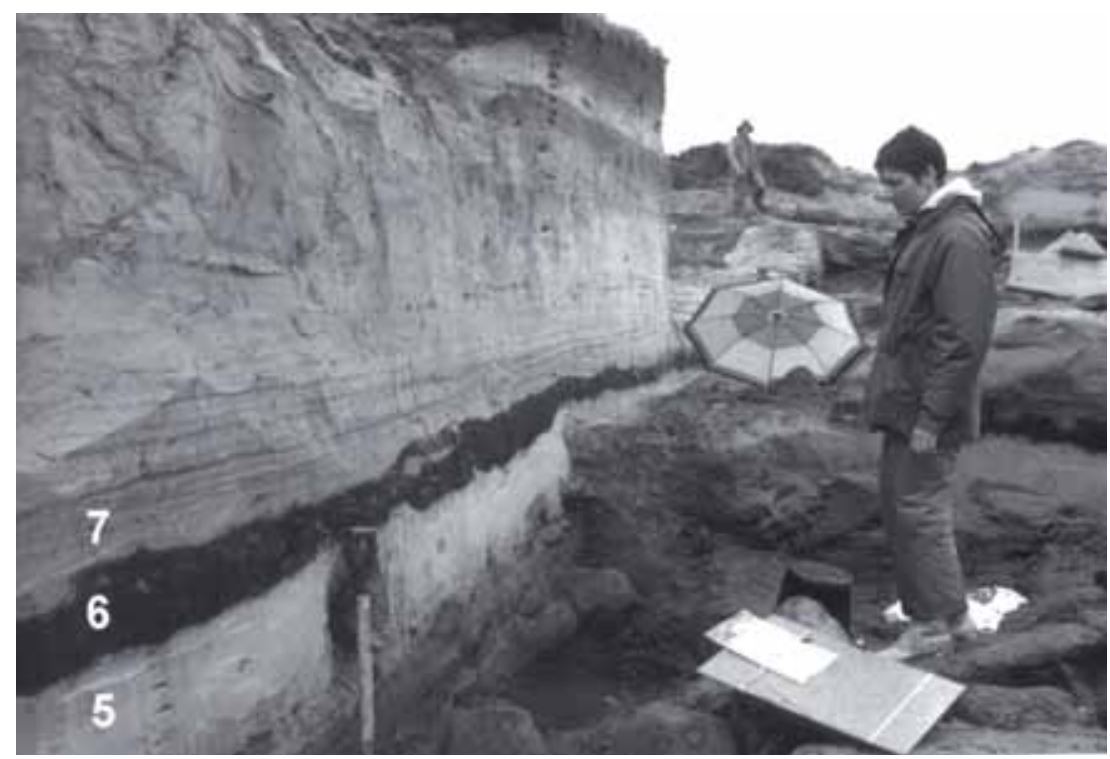

Figure 6: Soil section from the excavations at Sola, Jæren [3]. 
Table 1: Meteorological and oceanographical data for the coast of Jæren, southwestern Norway.

The 100 - year design wave conditions for the Sirevåg breakwater at $17 \mathrm{~m}$ water depth. Current velocity.

The highest observed water level in Stavanger.

The highest astronomical tide.

The mean sea level, MSL.
Significant wave height $\mathrm{H}_{\mathrm{s}, 100}=7.0 \mathrm{~m}$, and a mean wave period $\mathrm{T}_{\mathrm{z}, 100}=10.6 \mathrm{~s}$ [25].

The current velocity is highest northwards and may reach values up to approximately $0.3 \mathrm{~m} / \mathrm{s}$. $+1.84 \mathrm{~m}$ above Chart Datum, which is $0.20 \mathrm{~m}$ below Lowest Astronomical Tide (LAT)

$+1.11 \mathrm{~m}$ above Chart Datum. $+0.65 \mathrm{~m}$ above Chart Datum.

Hindcast data (1979-1997),

Grid Points 1261 and 1262

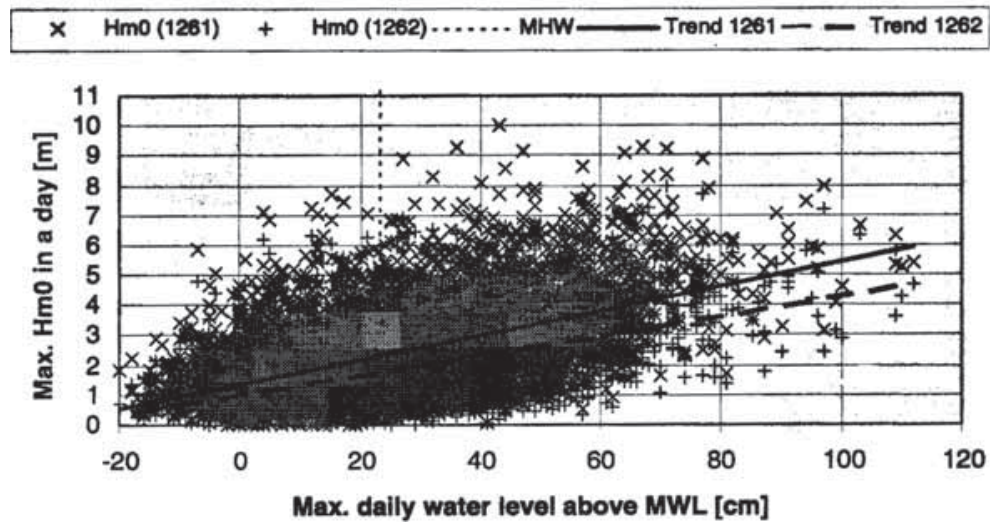

Figure 7: Correlation of water levels in Stavanger and wave heights along the Jæren coast [5].

are the standard grid points for which the Norwegian Meteorological Institute makes forecasts and hindcasts of waves on a routine basis. Figure 7 shows the results of the investigation by Løvås [5]. There is a scatter in the results, but the trend is, as expected, that there are high water levels when there are high waves.

The Scandinavian Peninsula was covered with an ice sheet of about 3-4000 m thickness during the last ice age. The land was pressed down and the relative water level was much higher than it is today. Prøsch-Danielsen [3] deals with sea levels along the southwestern coast of Norway during the latest $10,000-15,000$ years. She shows diagrams for the sea-level variation at several locations. Figure 8 shows a probable sea-level displacement curve for the Brusand area, Fig. 1.

As the Jæren area has been emerging during the last 4000 years, this may explain why the beaches have not suffered serious set-backs during recent times. Later we will show evidence that sand dunes in the Jæren area have grown significantly during the latest 100 years since marram grass was planted. 


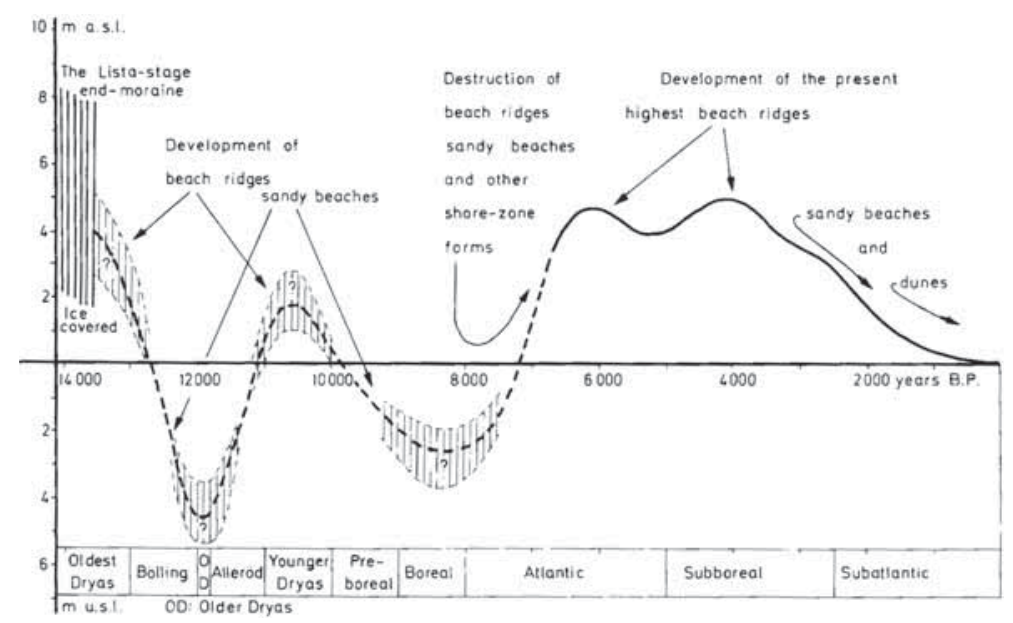

Figure 8: Probable sea-level displacement curve for the Brusand area, Fig. 1, based on geomorphological features from different sources [12].

\section{THE EMERGING FARMLAND}

Today the Jæren area is among the best farmland in Norway, Fig. 9. However, in the past the area was much hampered by sand drift during heavy storms. Sand drifts forced the farmers to abandon their farms. A map from 1806 [6] of the same area as that illustrated in Fig. 9 shows that the farms were located among sand ridges/dunes.

Lindanger [7] writes about the transformation from wealth to poverty for the tree farms at Orre, Reve and Vik at the end of the 17th century. The farmers asked for reduced taxes and land rental. Because of the long-term strong northwestern winds at that time, sand was blown into the farm fields, destroying or reducing them for the purpose of farming. Some of the farms were even abandoned. The sand drift was caused, as mentioned, by the strong northwestern winds, while farming itself might have damaged the vegetation such that the wind could more easily access the sand.

At that time Norway was part of the Danish kingdom. Marram grass had been used to some extent in Denmark by that time to dampen sand drift. The authorities in Copenhagen sent captain Knoph to survey the Jæren coast and draw up plans to combat sand drift by planting marram grass [6]. The Danish prime minister visited Stavanger in 1811. In its 3 December 1955 issue, the Stavanger Aftenblad newspaper reports from his diary when he visited the Jæren coastline, from which he gave an account on the damaging sand drift.

However, as Denmark was on the losing side during the Napoleonic wars, it ceded Norway to Sweden. Norway used the opportunity to acquire its own constitution and parliament in 1814, but had to accept the Swedish king as became until 1905, when Norway became an independent kingdom.

Norway was not a rich country in 1814 . Hence there was no focus from the Norwegian authorities to improve the conditions for the farmers on Jæren. An attempt was made to stop sand drift by means of wooden fences. These sand fences were apparently not extensively used and may have proven costly and not very effective in reducing the sand drift. It was not until at approximately 1870 that the issue of improving the conditions for the farmers on Jæren was raised again. By that time the long-term northwestern wind had started again with sand drifts into the farm fields [8]. 


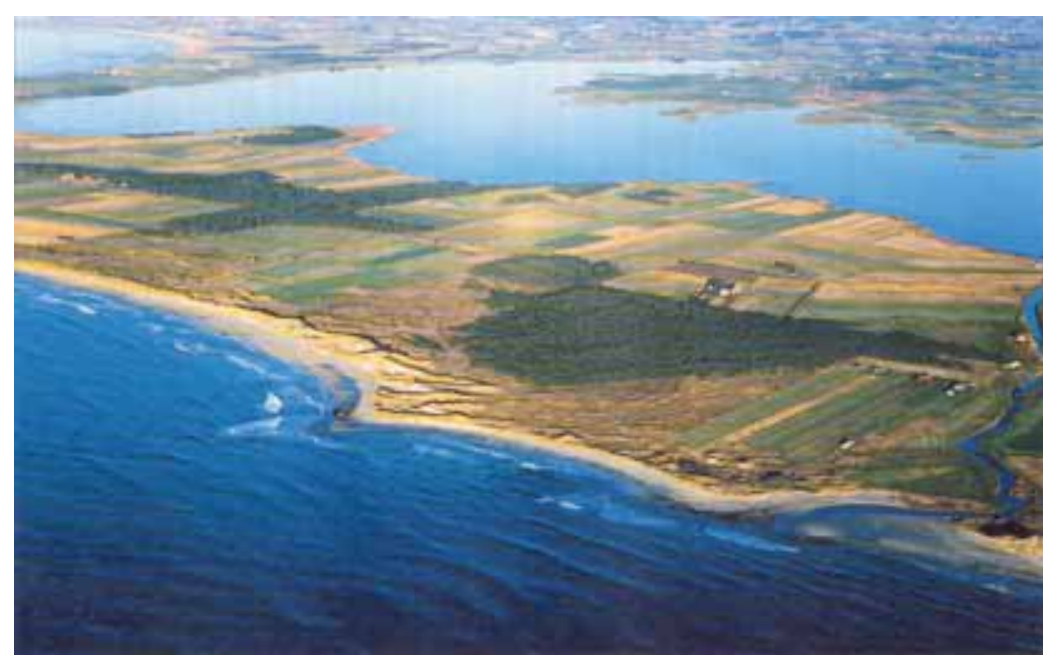

Figure 9: Orre in Klepp commune slightly south of Revtangen. Courtesy Norsk Fly and Flyfoto A/S. Picture taken 1995. (With permission from Fylkesmannen i Rogaland, Rogaland County Governor).

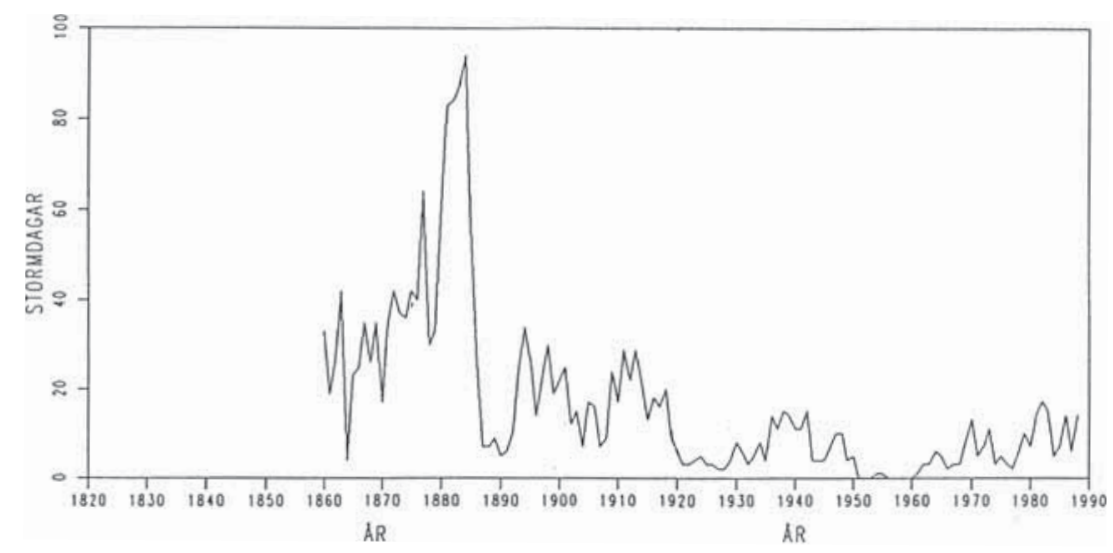

Figure 10: Number of storm days at Utsira lighthouse in the time period 1860-1988 [11].

The Norwegian author Arne Garborg [9] remembers when he, together with his father, as a 7-yearold boy, visited the farm of Torger Nærland in the late 1860s. The Nærland farm was located about one kilometer from the sea. Garborg then saw the large sand dunes, sand dunes that also covered farm land. During heavy winds the sand drifts reminded him of heavy snow storms and the sand drift even blocked the entrance doors.

In a school essay in 1924 about her grandfather Torger Nærland, Klara Gudmestad reports that heavy northern storms occurred in the late 1860s [10]. This is also verified by the information given in Fig. 10, showing the number of storm days at Utsira during the time period 1860-1988 [11]. Utsira is an island some $65 \mathrm{~km}$ northwest of the city of Stavanger, Fig. 1. When wind observations started 
in the 1860s the wind speed was judged visually. Different scales have been used for measuring wind speed. In 1867 a scale from 1 to 6 was used, with scale 5 indicating a storm. The Beaufort scale was introduced in 1919. This scale, from 1-12, can also be used for visually judged wind velocities. When wind velocity measurements in meters per second are used, "storm" is reported when there is 10 -minute mean velocity of $20.8-28.4 \mathrm{~m} / \mathrm{s}$. Although the wind observations, which are the background for Fig. 10, are not fully consistent due to the different scales used, the figure supports what Klara Gudmestad [10] wrote: "Towards the end of the 1860s heavy northern storms occurred".

Later on, when Arne Garborg visited the Nærland farm in the 1890s, he reported, again in "Letters of Knudahei", that where there had been sand dunes and sand drifts, there were now fertile farm fields and even fruit and berry gardens. The most important tool in the battle against the sand drifts was the planting of marram grass, organized by Torger Nærland. In addition some pine was also planted. So gradually the sand-ridden land was made fertile, as can be seen in Fig. 9.

\section{THE BEACHES AND SAND DUNES AT BORE-SELE, REVE AND BRUSANDEN}

As evidence of the positive effect of the marram grass we give a brief account of the beaches and sand dunes at Bore-Sele, Reve and Brusanden, Fig. 1.

\subsection{Bore-Sele}

Figure 11 shows a part of the beach at Bore-Sele. According to the landowner, the cabin in the background was built almost at the outer edge of the dune around 1965. Since then the dune has progressed some 100-150 m toward the sea. This is due to the marram grass, which covers the dunes. The marram grass requires new sand to be brought in from the sea since it is dependent on nutritious elements being brought in along with the sand from the sea. The diameter of the sand brought in by the wind is approximately $\mathrm{d}_{50}=0.20 \mathrm{~mm}$.

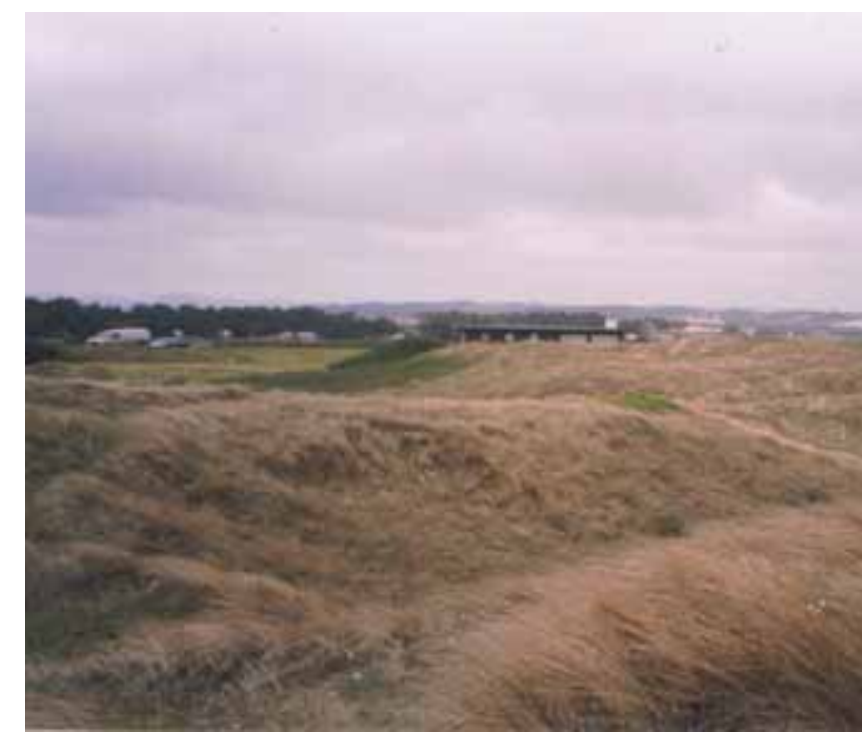

Figure 11: From the Bore-Sele beach in 2006. The photograph is taken landwards from the dunes' outer edge. May 2006. 


\subsection{Reve}

Another place where the sand dunes have grown significantly in the last 100 years is at Reve and Revtangen, Fig. 1.

In about 1870 a sailing mark was erected at Reve to help ships with their navigation during day time ("Day-time marker", no lights). Figure 12 shows an older painting from the Reve area where the "Day-time marker" is visible. Many ships went aground on the Jæren coast, and whenever this happened there was an auction of the ship wrecks. The painting shows that the area at Revtangen at the end of the 19th century was rather flat.

The "Day-time marker" was abandoned when new modern navigation became available in the beginning of the 20th century. It was, however, decided in 2004 to restore the "Day-time marker" as a piece of cultural heritage. The old concrete foundations were unburied to be used for the new "Day-time marker". Figure 13 is a photograph from the exhumation of the old foundations. The sand dunes are several meters high. The highest dunes today at Reve are approximately $7.5 \mathrm{~m}$ above sea level.

\subsection{Brusanden}

Brusanden is located at the southern end of Jæren, Fig. 1. Figure 14 shows a photograph of the area in 1963, revealing that there is hardly any vegetation between the small creek and the ocean.

Figure 15 shows the northern end of Brusanden in 2007. Although Marram grass was planted on Brusanden in 1894, it was not successful. Later, marram grass was planted on Kvalbeinsanden slightly north of Brusanden. This planting was successful. By natural spreading, the marram grass has also settled on Brusanden, whose dunes have grown considerably during the past 40-50 years.

Bird and Klemsdal [12] discuss changes of water levels between 1839 and 1939. They indicate a sea level fall of $7 \mathrm{~cm}$, but there are some uncertainties surrounding this figure. However, the sea level was probably $10-20 \mathrm{~cm}$ higher in 1708 than it is today. Lake Waulen was depicted on various maps

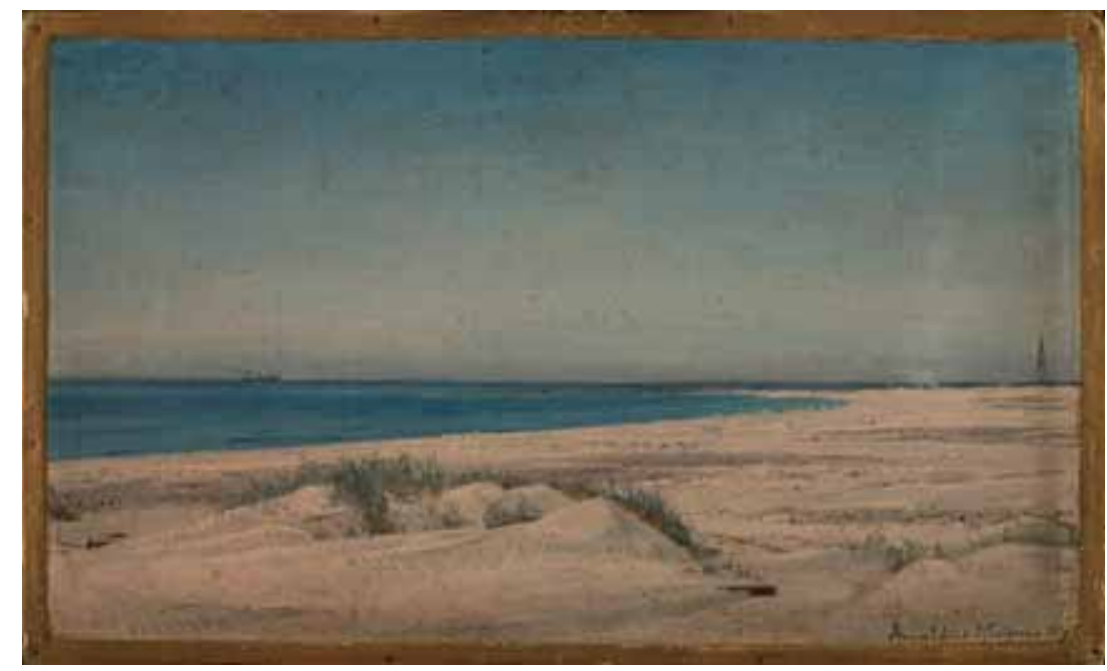

Figure 12: "Revet, Jæren”, painting by Amaldus Nielsen, 1893. Courtesy: Stenersenmuséet, Oslo. Foto: Richard Jeffries@ Stenersenmuséet. 


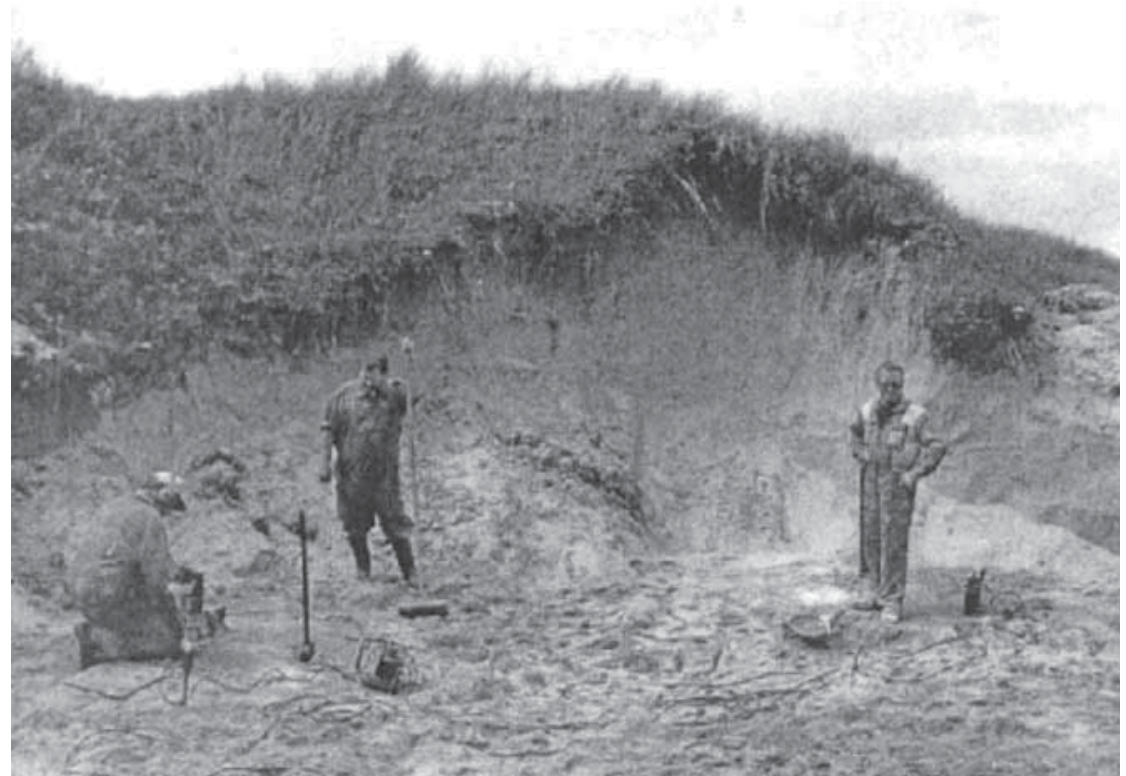

Figure 13: Uncovering of the old concrete foundations for the "Day - time marker" at Reve in 2004. The photograph and the information on the "Day - time marker" were provided by Thore Refve, Reve Jæren.

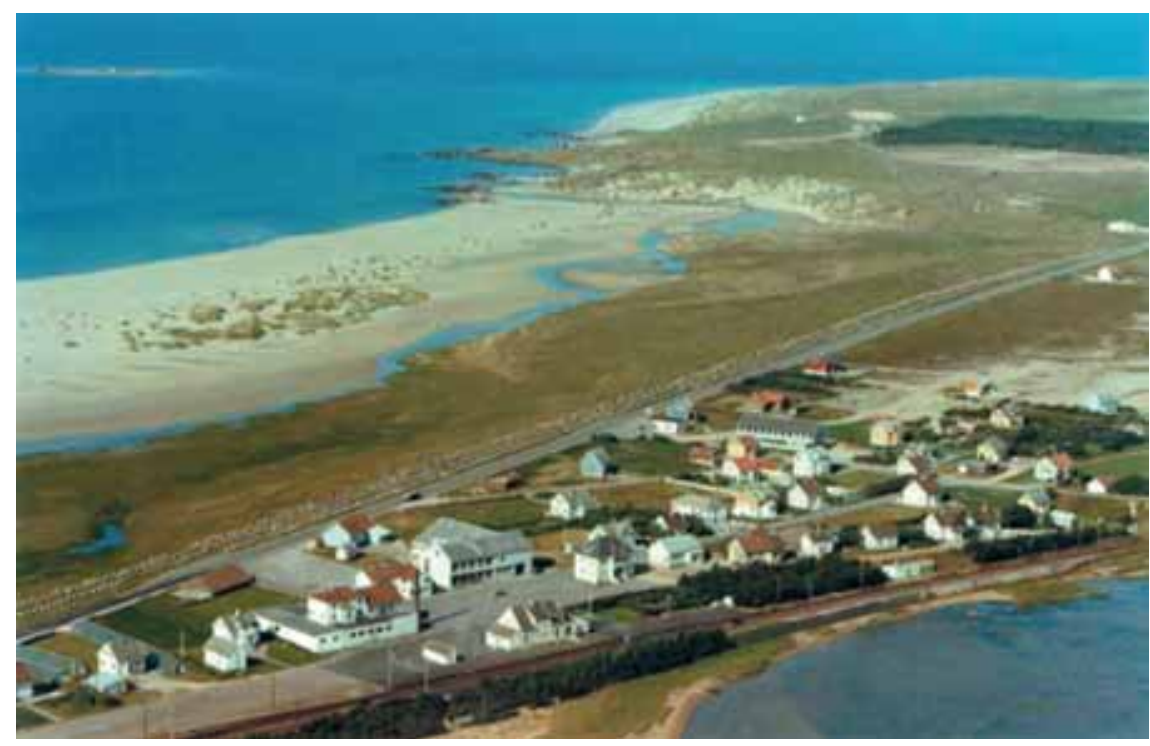

Figure 14: Brusand 1963. Foto: FjellangerWiderø A/S. Lake Waulen to the right. 


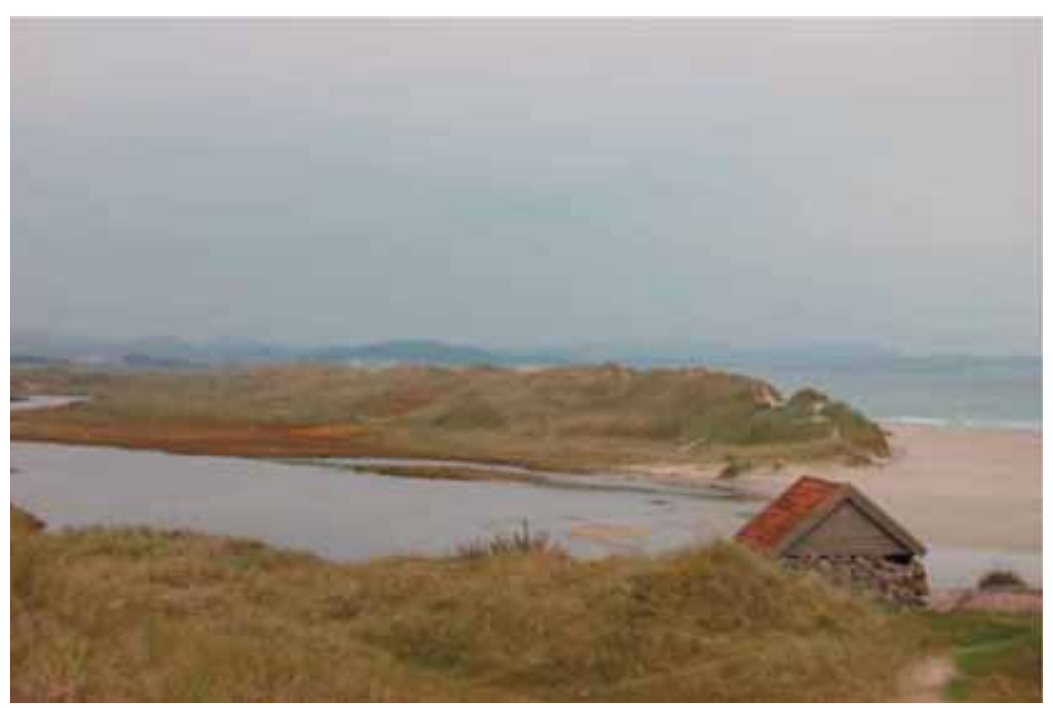

Figure 15: The northern end of Brusanden in 2007 with the outlet of the small river and Lake Waulen in the foreground.

as being larger than today and this may be due to higher water levels, but it may also be due to sand drifts through the years, which have caused the lake to be filled with sand in the same way as the lagoons at Lista, Reve, Bore-Sele sanden and Solasanden [12].

Liver Qvalbein, a local farmer, reports that the river from Lake Bjåland on the eastern side of Lake Waulen in the 1930s broke through Brusanden with access directly to the sea. This was probably due to the fact that part of the river system entering Lake Bjåland was diverted into another watershed due to hydropower development and hence less water was entering the river through Brusanden, causing the river to become shallow and finally break through in the midst of Brusanden.

\section{KELP AND ITS EFFECTS ON BEACH AND DUNE EROSION}

Kelp (Laminaria hyperborean) grows in many places along the Jæren coast. Figure 16 indicates the location of the kelp fields. The kelp grows on stones or rocks at a depth from 2 down to a water depth of approximately $20 \mathrm{~m}$, depending on the visibility in the water.

Figure 17 shows kelp plants, Laminaria hyperborean. When fully grown, these grow at a rate of approximately 10 plants per $\mathrm{m}^{2}$ and to a height of $1.5-2.0 \mathrm{~m}$. The lamina is approximately the same length. It takes about 5 years for a kelp plant to become fully grown.

Kelp is harvested in the kelp fields along the Jæren coast and is used for the production of alginates. The harvesting is regulated; the kelp fields are divided into smaller areas and each area is harvested every 5 years.

There has been some concern that the kelp harvesting increases beach and dune erosion. Sivertsen [13] and Berg and Munkejord [14] conclude that this most probably is the case. These investigations were, however, primarily based on some short-term measurements of beach recession. Fylkesmannen i Rogaland [15] reports on a one-day diver inspection in the Revtangen area and concludes that sand beyond $20 \mathrm{~m}$ depth cannot possibly be brought to the beach. As shown later, this is not necessarily true. The issue of wave damping by kelp and the effect kelp harvesting may have on beach and 


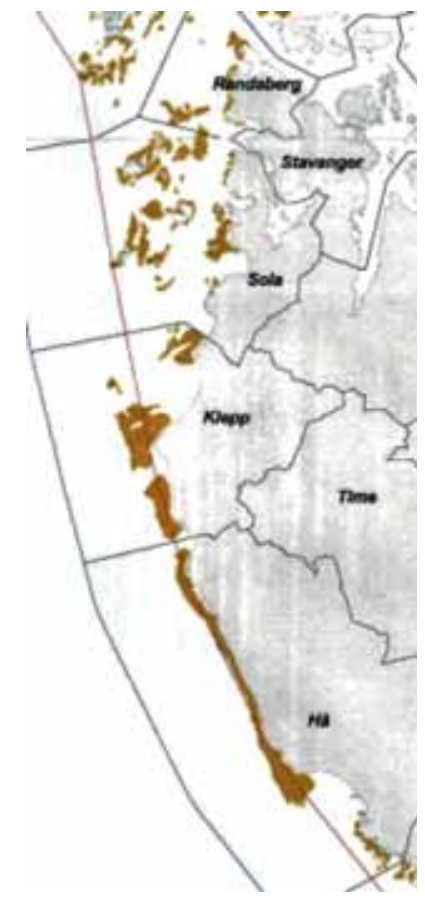

Figure 16: Location of kelp fields along the Jæren Coast (dark areas) [15].

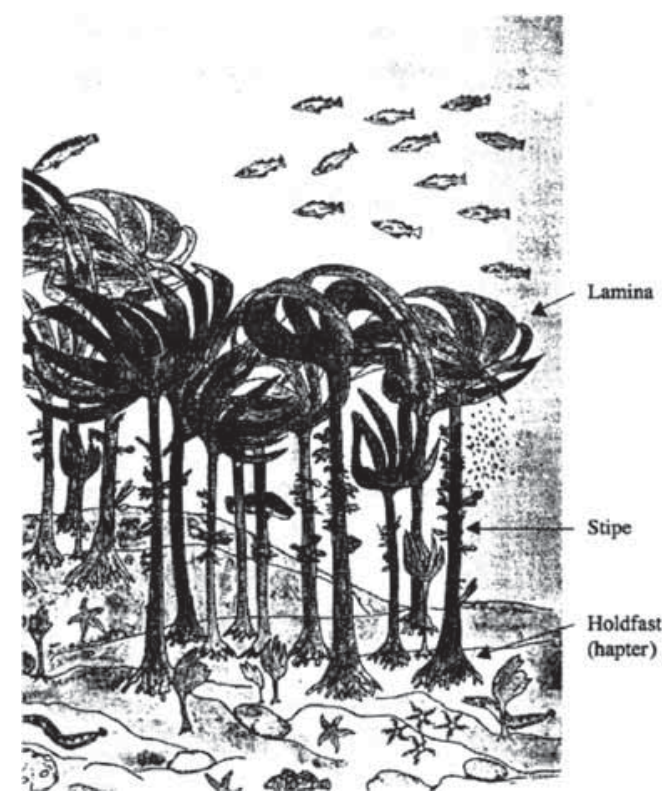

Figure 17: Kelp, Laminaria hyperborean, is split into three parts: the lamina, the stipe and the holdfast organ. The holdfast organ and the stipe are perennial, while the lamina changes every year. The new lamina moves the older one outward on the stipe until the old lamina leaves the stipe in spring time. 
dune erosion has been more thoroughly investigated by Dubi and Tørum [16], Dubi [17], Mork [18, 19], Dubi and Tørum [20], Løvås [5], Løvås and Tørum [21] and Løvås and Tørum [22].

It is true that kelp damps non-breaking waves significantly. However, in the surf zone, the wave breaking process takes much more energy out of the waves than the kelp does. Hence, harvesting of kelp does not significantly affect beach and dune erosion.

\section{CASE STUDY: MORUYA BEACH [23]}

Cowell et al. [23] describe the development of the Moruya Beach in Australia, which has grown significantly during the last 6000 years. The sand in the sea was deposited during a glacial period. The Moruya Beach is a pocket beach and no sand has been transported into the area either from rivers or along the beach. The water level has not varied significantly during the last 6000 years. Figure 18 shows the location of the Moruya Beach and marks a cross section through it. Figure 19 shows the cross section as marked on Fig. 18.

The rate of propagation of sand volume into the beach has been decreasing and today stands at approximately $4 \mathrm{~m}^{3} / \mathrm{year} / \mathrm{m}$ beach length. As a comparison we have estimated that the rate of sand propagation into the dunes at Bore, Fig. 11, has been approximately $15 \mathrm{~m}^{3} /$ year/m beach length during the past 45 years.

It is interesting to note that for the Moruya Bay, Fig. 19, the sand has been brought up from approximately $50 \mathrm{~m}$ water depth. Thus the findings at Moruya Beach give further evidence of growing sand beaches, similar to the situation for the beaches at Jæren.

\section{SUGGESTED EXPLANATION FOR THE GROWTH OF THE SAND DUNES AT JÆREN}

Beach erosion has not been of much concern on the Jæren coast, even though the situation after large storms has appeared dramatic, Fig. 5. Following the beach erosion incidents, the dunes have built up again. It is a fact that the sand dunes at Bore-Sele, Reve and Brusanden have been growing during the past 50-100 years. The planting of marram grass has contributed significantly to this fact.

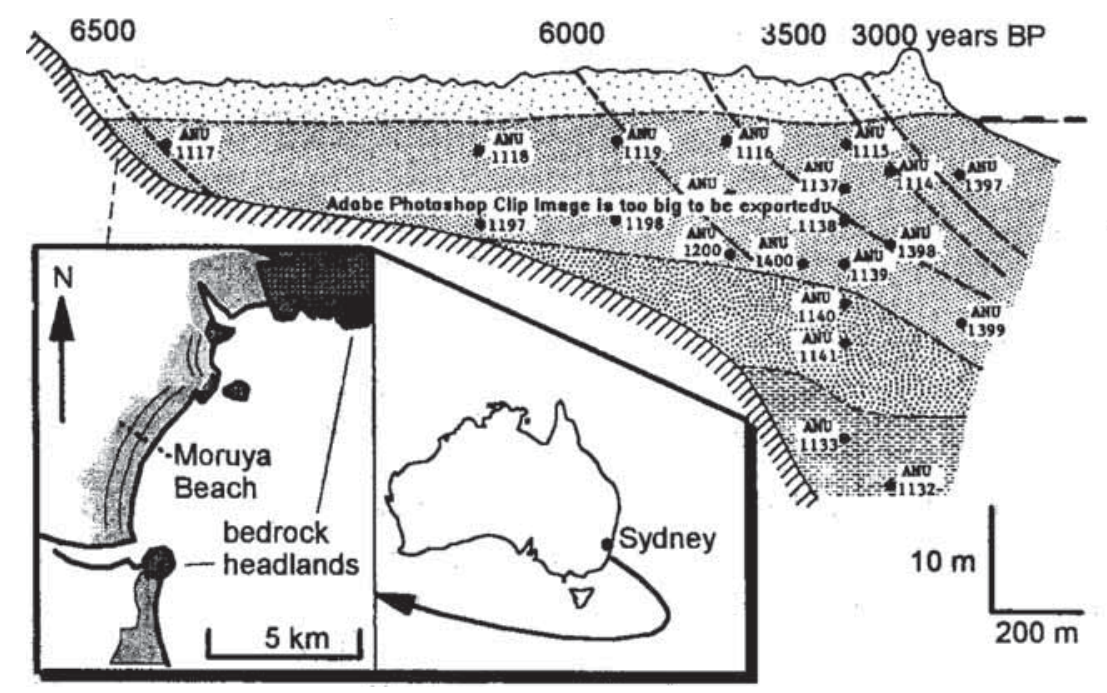

Figure 18: Moruya Beach [23]. The time contours, years before present (BP), were determined from $\mathrm{C}^{14}$ analysis of organic material obtained from drilling on the beach. 


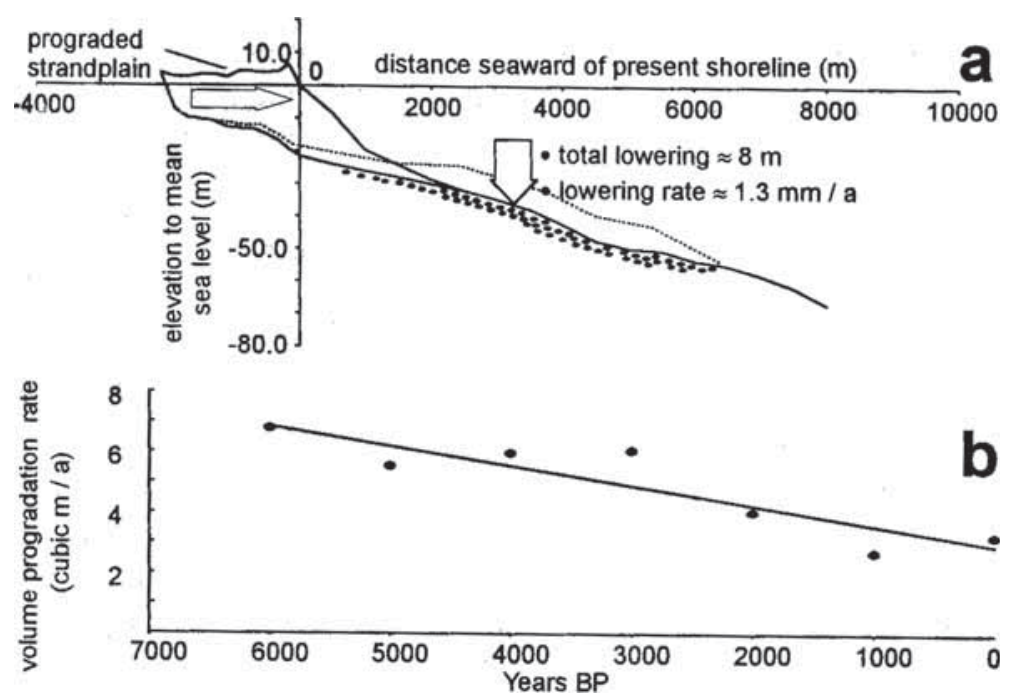

Figure 19: Moruya Beach [23]. The cross section is an interpretation of the lowering of the sea bed. The dotted line is the bottom level 6000 years ago. The lower diagram shows the rate of propagation of sand volume into the beach.

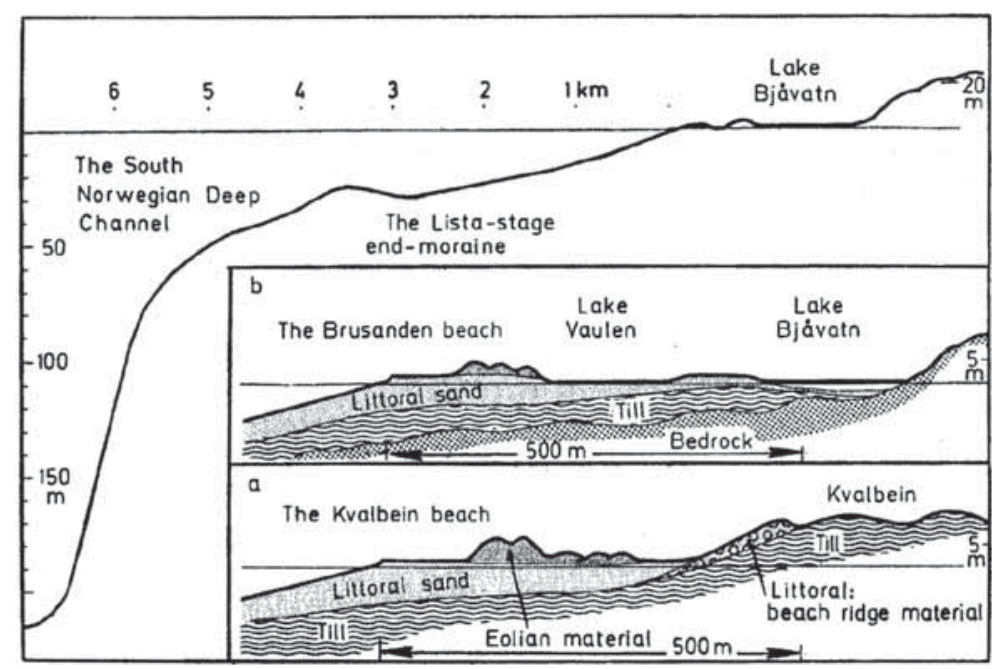

Figure 20: Profiles at Brusand and Kvalbein [12]. The indicated thicknesses of sand, etc., are assumptions and not based on borings (personal communication between Klemsdal and Tørum).

The beaches at Bore-Sele, Reve and Boresanden are a mixture of coarse and fine sand. The fine sands, $\mathrm{d}_{50} \approx 0.2 \mathrm{~mm}$, is to a large extent blown inland and is today caught by the marram grass, which leads to the present build-up of the dunes. Figure 20 shows the cross-sections at the Kvalbein and Brusanden beaches and dunes, indicating that the sand layer at the beach at present is in the order of $5 \mathrm{~m}$. 
In the past, the wind drift of sand has been a nuisance to farmers in the area, although the problems caused by the sand drift were resolved in the late 19th century. The struggle by the farming population to stop the sand drift by planting marram grass should be appreciated, recording the usefulness of involving the local population in solving problems caused by climatic variations and damaging environmental conditions.

We have documented that there is transport of sand from the sea to the coast. Since there are no big rivers entering the sea at Jæren, the sand must come from the offshore glacial deposits. Sand and gravel from a considerable water depth along the Jæren coast may be moved toward the coast. It is well known that during heavy storms, sand at the Ekofisk oil field at $70 \mathrm{~m}$ water depth in the North Sea moves (Bratteland and Bruun, referred to in Tørum [24]).

Bird and Klemsdal (1986) also describe what they think is the reason for the growth of the sand dunes at Brusand. They refer to the varying water levels, Fig. 8, confirming that it is reasonable to assume that there is a large transport of sand from the sea to the beach and the dunes.

\section{REFERENCES}

[1] Sejrup, H.P., Iversen, M., Larsen, E., Landvik, J.Y. \& Janocko, J., A stage 7 marine interglacial record (the Grødaland interglacial) on Jæren, south western Norway; foraminiferal, stable isotopes and amino acid evidence. Boreas, 28, pp. 326-346. Oslo, 1999.

[2] Larsen, E., Sejrup, H.P., Janocko, J., Landvik, J.Y., Stalsberg, K. \& Steinsund, P.I., Recurrent interaction between the Norwegian Channel Ice Stream and terrestrial-based ice across southwest Norway. Boreas, 29, pp. 185-203. Oslo, 2000.

[3] Prøsch-Danielsen, L., Sea-level studies along the coast of southwestern Norway. With emphasis on three short-lived Holocene marine events. AmS - Skrifter 20. Museum of Archaeology, Stavanger. National Research Centre for Paleostudies and Conservation, Stavanger, Norway, 2006.

[4] Selsing, L. \& Mejdahl, V., Aeolian stratigraphy and thermoluminescence dating of sediments of late Holocene age from Sola, southwest Norway. Boreas, 23, pp. 92-104, 1994. doi: http:// dx.doi.org/10.1111/j.1502-3885.1994.tb00589.x

[5] Løvås, S.M., Hydro-physical conditions in kelp forest and the effect on wave damping and dune erosion-a case study on Laminaria hyperborean. Dr. Ing. thesis, Department of Structural Engineering, Faculty of Civil and Environmental Engineering, Norwegian University of Science and Technology, Trondheim, Norway, 2000.

[6] Knoph, Report on a survey of the Jæren area with respect to the sand drift problems and with a proposal to mitigate the sand drift problems (in Danish, written by hand in Gotish style), 1806.

[7] Lindanger, B., Klepp bygdesoge fram til 1837. Klepp kommune, 1990. (The history of the Klepp municipality up to 1837 . Issued by Klepp municipality, 1990). (Klepp municipality is a municipality on Jæren), 1990.

[8] Gudmestad, K., Om bestefar Torger Edland Nærland. (About my grandfather Torger Edland Nærland). (In Gudmestad), 1924.

[9] Garborg, A., Knudahei-brev. (Letters from Knudaheio). Publisher Aschehoug: Kristiania (Oslo), 1904.

[10] Gudmestad, O.T. \& Undheim Gudmestad, R., The Gudmestad Family (Gudmestad slekta. In Norwegian). Publisher Jærprent: Bryne, Norway, 1998.

[11] Hønsi, I., Storm days at Utsira, Skomvær, Ingøy and Fruholmen. Report of the Norwegian Petroleum Directorate. Report No. OD-89-79, 1989. 
[12] Bird, E.C. \& Klemsdal, T., Shore displacement and the origin of the lagoon at Brusand, southwestern Norway. Norsk geografisk tidskrift. The Norwegian Journal of Geography, 40, pp. 27-35, Oslo, 1986.

[13] Sivertsen, K., Kelp harvesting as a possible cause of increased erosion of the beaches at Jæren. Report 1985:6 of the Nordland College, Bodø, Norway. (In Norwegian), 1985.

[14] Berg, B.S. \& Munkejord, Aa, Do the beaches on Jæren disappear? Yearly Report from the Department of the Environment, The Governor of Rogaland County (in Norwegian), 1991.

[15] Fylkesmannen i Rogaland, Bunn- og tareskogsundersøkelse ved Revtangen - Orre elva, 2006. (In Norwegian). (Rogaland County Governor, Bottom and kelp forest investigations at Revtangen - Orre river, 2006).

[16] Dubi, A. \& Tørum, A., Wave damping by kelp vegetation. Proceedings of the 24th International Conference on Coastal Engineering, October 23-28, 1994, Kobe, Japan. ASCE, 1994.

[17] Dubi, A., Damping of water waves by submerged vegetation - a case study on Laminaria hyperborea. Dr. Ing. Thesis, Department of Structural Engineering, The Norwegian Institute of technology (NTH), University of Trondheim (now Norwegian University of Science and Technology), November 1995.

[18] Mork, M., The effect of kelp in wave damping. Sarsia, 80, pp. 323-327, Bergen, 1996a. ISSN 0036-4827.

[19] Mork, M., Wave attenuation due to bottom vegetation, Waves and Nonlinear Processes in Hydrodynamics, eds. J. Grue et al., Klüver Academic Publishers: The Netherlands, 1996b.

[20] Dubi, A. \& Tørum, A., Wave energy dissipation in kelp vegetation. Proceedings of the 25th International Conference on Coastal Engineering, September 1996, Orlando, Florida, USA. ASCE, 1996

[21] Løvås, S.M. \& Tørum, A., Effect of submerged vegetation upon wave damping and run-up on beaches: a case study on Laminaria hyperborean. Proceedings of the 27th International Conference on Coastal Engineering, July 2000, Sydney, Australia. ASCE, 2000.

[22] Løvås, S.M. \& Tørum, A., Effect of kelp Laminaria hyperborean upon sand and dune erosion and water particle velocities. Coastal Engineering, 44, Elsevier, 2001.

[23] Cowell, P.J., Stive, M.J.F., Roy, P.S., Kaminsky, G.M., Buijsman, M.C., Thom, B.G. \& Wright, L.D., Shoreface supply to beaches. Proceedings of the 27th International Conference on Coastal Engineering, July 16-21, Sidney, Australia, 2000.

[24] Tørum, A., Coastal Engineering. Lecture notes, NTNU. (In Norwegian), 1992.

[25] Tørum, A., Løset, S. \& Myhra, H., Reshaping of the Sirevåg berm breakwater - comparison between model and prototype. Proceedings of the International Coastal Symposium, June 2005, Høfn, Iceland, 2005.

[26] Sejrup, H.P., Landvik, J., Larsen, E., Eirikson, J., Janocko, J. \& King, E., The Jæren area; a border zone of the Norwegian channel ice stream. Quaternary Science Reviews, 17, pp. 801-812, 1998. doi: http://dx.doi.org/10.1016/S0277-3791(98)00019-5

[27] Sjulsen, O.E., Sedimentologisk analyser og geomorfologisk kartlegging I kystnære deler av Sola og Kleppe kommuner på Jæren. Hovedfagsoppgave i geografi, Geografisk institutt, Universitetet i Oslo. (In Norwegian). (Sedimentological analysis and geomorphological mapping in near coastal areas in the communities Sola and Kleppe on Jæren. Master thesis, Department of Geography, University of Oslo, Norway), 1982. 